\title{
Peranan Pengasuhan Kakek dan Nenek terhadap Perilaku Prososial Anak Usia Dini
}

\author{
Retno Ika Haryani ${ }^{1}$, Dimyati ${ }^{2}$, Puji Yanti Fauziah ${ }^{3}$ \\ Pendidikan Anak Usia Dini, Universitas Negeri Yogyakarta(1) \\ Pendidikan Olahraga, Universitas Negeri Yogyakarta(2) \\ Pendidikan Luar Sekolah, Universitas Negeri Yogyakarta(3) \\ DOI: $\underline{10.31004 / \text { obsesi.v6i1.1196 }}$
}

\begin{abstract}
Abstrak
Pengasuhan oleh kakek nenek banyak terjadi di Indonesia. Hal ini dapat terjadi disebabkan oleh banyak faktor yakni perceraian orang tua, depresi yang dialami ibu, kematian orangtua, dan kesulitan ekonomi yang menyebabkan orangtua menjadi TKI diluat negeri. Studi ini menggunakan metode kajian literatur untuk mengetahui peranan pengasuhan kakek dan nenek terhadap perilaku prososial anak usia dini. Pada pelaksanaannya pengasuhan kakek dan nenek ini banyak dipengaruhi oleh pola pengasuhan yang diterapkan kepada anak usia dini ( $\mathrm{cucu}$ ) yang dapat memberi dampak psikologis bagi anak usia dini. Dampak dari pola pengasuhan permisif menyebabkan anak cenderung menarik diri dan kesulitan bergaul dengan teman sebayanya. Hal yang dilakukan dalam mengatasi hal ini dengan mengajak kakek dan nenek untuk lebih mempelajari pengasuhan terbaik dalam mengasuh anak usia dini ( $\mathrm{cucu}$ ) yakni dengan mengajak mereka menghadiri kegiatan parenting, agar hubungan kakek dan nenek dengan anak usia dini (cucu) menjadi lebih baik dan anak dapat berkembang dengan optimal.
\end{abstract}

Kata Kunci: pengasuhan kakek dan nenek; prososial; anak usia dini.

\begin{abstract}
Parenting by grandparents is common in Indonesia. This can occur due to many factors, namely parental divorce, depression experienced by mothers, death of parents, and economic difficulties that cause parents to become migrant workers abroad. This study uses a literatur review method to determine the role of grandparents' parenting in early childhood prosocial behavior. In practice, the care of grandparents is influenced by the pattern of care applied to early childhood (grandchildren) which can have a psychological impact on early childhood. The impact of permissive parenting causes children to tend to withdraw and have difficulty getting along with their peers. This is done in order to overcome this by inviting grandparents to learn more about the best parenting in caring for early childhood (grandchildren), namely by inviting them to attend parenting activities, so that the relationship between grandparents and early childhood (grandchildren) becomes better and their children can develop optimally.
\end{abstract}

Keywords: grandparenting, prosocial; early childhood

Copyright (c) 2021 Retno Ika Haryani, Dimyati, Puji Yanti Fauziah

$\triangle$ Corresponding author:

Email Address : retnoika.2019@student.uny.ac.id ( Jalan Melati Samirono CT VI 257, YogYakata, Indonesia) Received 11 Januari 2021, Accepted 3 March 2021, Published 12 April 2021 


\section{PENDAHULUAN}

Anak usia dini merupakan anak yang sedang dalam proses perkembangan kepada tahap kehidupan selanjutnya. Anak usia dini adalah individu yang mengalami proses perkembangan dan pertumbuhan yang pesat. Pada tahap tumbuh kembang anak ini dibutuhkan suatu pedoman dasar agar dapat tercapainya perkembangan yang optimal. Dalam Standar Nasional Pendidikan Anak Usia Dini, meliputi aspek nilai agama dan moral, fisik-motorik, kognitif, bahasa, sosial emosional, dan seni (Permendikbud, 2014). Untuk mencapai semua aspek perkembangan tersebut dengan maksimal dibutuhkan stimullasi yang tepat serta keterlibatan keluarga secara aktif.

Keluarga merupakan salah satu unit sosial dalam masyarakat yang terdiri atas suami, istri dan anak yang saling berinteraksi dan memiliki hubungan yang sangat erat untuk mencapai suatu tujuan tertentu(Kemenpppa, 2009). Tujuan Ini dapat dicapai jika keluarga memahami semua proses yang terjadi dan orangtua memahami fungsi serta perannya dalam keluarga. Orangtua memiliki fungsi utama yaitu berupa perlindungan bagi anak dan menyampaikan nilai-nilai dalam kehidupan (Minuchin, 1974). Sedangkan peran orangtua tidak hanya dalam pemenuhan kebutuhan anak berupa asupan nutrisi, namun juga berupa stimulasi dan kasih sayang (Habibi,2018:4-5). Hal ini dapat diwujudkan dalam pembimbingan dan pengasuhan anak secara tepat.

Pembimbingan dan pengasuhan yang ideal seharusnya dilakukan oleh orangtua kepada anaknya, namun keluarga indonesia saat ini menujukkan bahwa banyak pasangan orangtua yang bekerja. Hal ini sedikit banyaknya mempengaruhi proses orangtua dalam membimbing dan menggasuh anaknya, sehingga kadang dalam pengasuhan orangtua membutuhkan support dari orang lain dan mengharuskan anak mendapat pengasuhan dari kakek dan nenek mereka (Ingersoll-Dayton et al., 2020). Pengasuhan oleh kakek dan nenek ini sering terjadi dalam masyarakat, situasi ini disebabkan oleh beberapa permasalahan yang terjadi pada keluarga sang anak yakni terkendala financial dalam keluarga dan berbagai penyebab lainnya. Peralihan pengasuhan kepada kakek dan nenek ini bisa berupa pengasuhan rutin teratur, maupun sebagai pengasuh pengganti bagi anak, di indonesia sering disebabkan oleh sang orangtua bekerja sebagai TKI(Tenaga Kerja Indonesia) diluar negeri (Fono et al., 2019). Terlepas dari pengasuhan yang sementara atau menyeluruh oleh kakek nenek, sedikit banyaknya mampu berpengaruh pada pembentukan perilaku prososial pada anak usia dini.

Perilaku prososial merupakan suatu perilaku yang mencerminkan peduli pada keadaan dan hak, perhatian, empati serta memberi manfaat bagi orang lain (Santrock, 2013). Perilaku prososial menjadi salah satu perilaku yang penting untuk dikembangkan sejak anak masih berusia dini. Hal ini sesuai dengan pendapat yang menyatakan bahwa perilaku prososial penting untuk dikembangkan pada anak sejak masih berusia dini, karena perilaku prososial akan berpengaruh terhadap kemampuan anak dalam berperilaku dan mengelola emosi ketika berhubungan dengan orang lain (Knafo \& Plomin, 2006). Hal ini dapat tercapai tidak lepas dari peran serta gaya pengasuh. Oleh karena itu dibutuhkan stimulasi yang tepat oleh sang kakek dan nenek dalam mengembangkan perilaku prososial anak agar pendidikan pada anak usia dini dapat berjalan sesuai harapan dan anak berkembang dengan optimal serta anak mampu menjadi pribadi dewasa dimasa depan yang penuh rasa kasih sayang serta peduli dengan sesama.

Studi ini berupa kajian literatur dengan harapan dapat memberi kontibusi terhadap ilmu pengasuhan anak usia dini terkait dengan pengasuhan oleh kakek dan nenek dalam upaya mengembangkan salah satu aspek moral dan social emosional anak berupa perilaku prososial anak usia dini. Peranan pengasuhan kakek dan nenek terhadap perilaku prososial anak usia dini ini berbai pada beberapa sub bagian pembahasan yang terdiri dari peran pengasuhan kakek dan nenek, gaya pengasuhan kakek dan nenek, Faktor yang mempengaruhi gaya pengasuhan kakek dan nenek, Perilaku prososial anak usia dini, Bentuk- 
DOI: 10.31004/obsesi.v6i1.1196

bentuk Perilaku Prososial, serta Faktor yang mempengaruhi perilaku prososial pada anak usia dini. Beberapa poin tersebut akan dijabarkan pada bagian pembahasan.

\section{METODOLOGI}

Berdasarkan latar belakang masalah mengenai pengasuhan oleh kakek nenek terhadap perilaku prososial pada anak usia dini. Jenis penelitian ini adalah deskriptif dengan menggunakan pendekatan kualitatif. Williams dalam Moleong (2012:5) menulis bahwa penelitian kualitatif adalah pengumpulan data pada suatu latar alamiah, dengan menggunaka metode alamiah, dan dilakukan oleh orang atau peneliti yang tertarik secara alamiah. Deskriptif adalah data yang dikumpulkan adalah berupa kata-kata, gambar, dan bukan angka-angka. Hal ini disebabkan oleh adanya penerapan metode kualitatif. Selain itu, semua dikumpulkan berkemungkinan menjadi kunci terhadap apa yang sudah diteliti.

Studi ini berupa studi Kajian literatur yang digunakan untuk mendapatkan jawaban atas permasalahan penelitian melalui literatur dan data-data dari penelelitian terdahulu yang relevan yang kemudian dijadikan sebagai sumber utama data sehingga tidak lagi membutuhkan penelitian secara langsung dilapangan(Hasanah \& Sugito, 2020). Studi literatur ini telah berisikan tentang suatu konten penting berupa suatu topik yang diteliti dengan mengumpulkan literatur dan dinyatakan secara eksplisit terkait masalah terkait topic yang diteliti , baik dari segi subjek yang akan diteliti dan lingkungan manapun dari sisi hubungan penelitian dengan tersebut dengan penelitian lain yang relevan (Wekke, 2020).

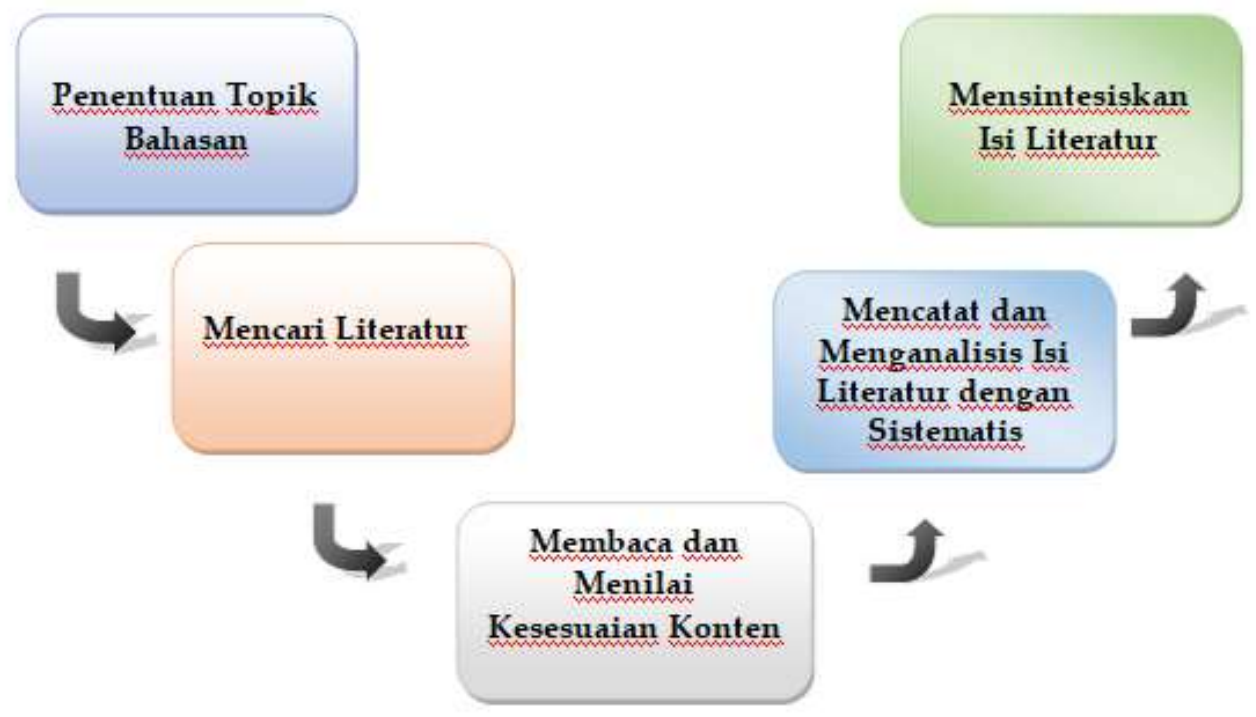

Gambar 1. Langkah-langkah Kajian Literatur

Sesuai dengan langkah sebagai acuan dalam kajian literatur pada gambar 1, alur atau langkah kajian literatur terbagi dalam beberapa langkah yakni diawali dengan mencari literatur yang sesuai dengan tema dan memilah secara efisien literatur dari sumber informasi, memastikan literatur memenuhi syarat tertentu, memeriksa dan menganlisis isi literatur secara berurutan, serta diakhiri dengan mensintesiskan isi literatur(Nasution, 2017).

\section{HASIL DAN PEMBAHASAN}

\section{Peran Pengasuhan Kakek Dan Nenek}

Dalam era sekarang, di mana ilmu dan teknologi berkembang dengan pesat, menyebabkan semakin terkikisnya sekat-sekat yang memisahkan antara pria dan perempuan untuk bekerja. Beralihnya seorang istri manjadi wanita karir kemudian banyak keluarga yang memiliki peran ganda, karena kendala ini menjadikan Tergantinya peran orang tua dalam 
mengasuh anak-anak mereka diperkuat apabila kedua orang tua mereka berada jauh dengan anaknya (Zakaria \& Alif, 2020). Pengasuhan erat kaitannya dengan kemampuan suatu keluarga atau rumah tangga dan komunitas dalam hal memberikan perhatian, waktu, dan dukungan untuk memenuhi kebutuhan fisik, mental dan sosial anak-anak yang sedang dalam masa pertumbuhan serta bagi anggota keluarga lainnya.

Pada proses pengasuhan oleh kakek dan nenek biasanya dipengaruhi oleh usia kakek dan nenek dapat yng kemudian berdampak pada hubungan antara kakek dan nenek dengan anak usia dini (cucu)(Drew et al., 1998). Dalam kondisi lain disebabkan oleh beberapa faktor yaitu: a. kurang memberikan aturan-aturan yang tegas selalu menuruti keinginan anak; $b$. orang tua yang bekarja; c. keaadaan salah orangtua meninggal sehingga harus menjalani kehidupan dengan salahsatu orangtua saja; dan d. keadaan keluarga yang orangtunya bercerai. Dalam pengasuhan oleh kakek dan nenek yang tidak mempunyai aturan yang tegas atas kesalahan yang dibuat anak, hal ini disebabkan karena adanya jarak yang jauh antara generasi kakek nenek dan anak(Zakaria \& Alif, 2020).

Pengasuhan oleh kakek dan nenek memiliki beberapa tipologi yaitu a. pengasuhan yang dilakukan oleh kakek dan nenek tidak berupa perawatan secara teratur namun dalam beberapa waktu tertentu saja; $b$. peran pengasuhan yang dilakukan oleh kakek dan nenek dan menjadi wali dari cucu mereka; serta c. peran pengasuhan oleh kakek dan nenek yang cenderung sedikit atau bahkan tidak terlibat pada pengasuhan cucu atau anak usia dini (Sanders \& Mazzucchelli, 2018). tabel 1.

Tipologi gaya pengasuhan kakek nenek terdiri dari 5 jenis sebagaimana diuaikan pada

Tabel 1. Tipologi gaya pengasuhan kakek nenek

\begin{tabular}{|c|c|c|}
\hline No & $\begin{array}{l}\text { Tipologi Gaya } \\
\text { Pengasuhan }\end{array}$ & Karakteristik \\
\hline 1. & Berpengaruh. & $\begin{array}{l}\text { Kakek dan nenek memiliki kesempatan terlibat dalam mayoritas kegiatan } \\
\text { cucu(anak usia dini) serta memiliki kelekatan yang cukup besar. }\end{array}$ \\
\hline 2. & Mendukung. & $\begin{array}{l}\text { Kakek nenek ikut serta mendukung cucu mereka sesekali dalam peran } \\
\text { otoritas dan disiplin dakam kehidupan cucu tetapi pada tingkat } \\
\text { keterlibatan yang lebih rendah }\end{array}$ \\
\hline 3. & Pasif. & $\begin{array}{l}\text { Kakek-nenek pasif bertemu mereka cucu setidaknya sebulan sekali tetapi } \\
\text { terlibat dalam kegiatan yang relatif sedikit hubungan dengan mereka. }\end{array}$ \\
\hline 4. & $\begin{array}{l}\text { Berorientasi } \\
\text { Otoritas }\end{array}$ & $\begin{array}{l}\text { peran membantu, namun cenderung pasif dan tampaknya } \\
\text { mempertahankan lebih kontak tidak langsung dengan cucu mereka } \\
\text { daripada berinteraksi langsung dia laki-laki atau dia perempuan. }\end{array}$ \\
\hline 5. & Terpisah & $\begin{array}{l}\text { Kakek-nenek yang terpisah yang paling tidak terlibat dalam urusan cucu } \\
\text { mereka. Kakek-nenek yang terpisah cenderung lebih jarang melihat cucu } \\
\text { mereka rata-rata; kurang dari setengahnya melakukan kontak tatap muka } \\
\text { dengan cucu mereka lebih dari sekali per bulan }\end{array}$ \\
\hline
\end{tabular}

Sumber: (Mueller et al., 2002).

Berdasarkan penjabaran yang telah dilakukan dapat disimpulkan bahwa peran pengasuhan oleh kakek dan nenek terhadap cucu sangat beragam terlepas dari kondisi keluarga sang anak. Dalam hubungan kakek nenek dengan cucu( anak usia dini) menjadi suatu faktor penting dalam suksesnya pelaksanaan peran yang kakek nenek miliki dalam pengasuhan anak usia dini.

\section{Gaya Pengasuhan kakek dan Nenek}

Secara umum pola pengasuhan seperti dijelaskan oleh Baumrind dalam shaffer (2008:376), terdapat empat macam pola asuh orang tua dijelaskann pada tabel 2. 
Tabel 2. Empat macam pola asuh orang tua

\begin{tabular}{|c|c|c|}
\hline No & Pola Asuh & Karakteristik \\
\hline 1 & Otoriter & $\begin{array}{l}\text { Pola pengasuhan ini mana orang tua lebih memberikan banya aturan } \\
\text { yang sangat ketat dan mengharapkan anaknya lebih mematuhi peraturan } \\
\text { yang cenderung sepihak dan jarang memberikan penjelasan kepada anak } \\
\text { dalam mematuhi peraturan sehingga jika anak tidak mematuhi aturan } \\
\text { akan diberilan hukuman sering menghukum anak fisik, serta orangtua } \\
\text { terlalu banyak mengatur kehidupan anak. Akibat dari pengasuhan } \\
\text { tersebut mengakibatkan anak cenderung memiliki sifat mudah } \\
\text { tersinggung, penakut, pemurung tidak bahagia, mudah terpengaruh dan } \\
\text { mudah stres, tidak mempunyai masa depan yang jelas, tidak mempunyai } \\
\text { sahabat, gagap atau rendah diri (Kartika, Malik, \& Saugi, 2020; Sofiani, } \\
\text { Mufika, \& Mufaro'ah, 2020; casmini, } 2007: 7 \text {; Subroto,2000:59). }\end{array}$ \\
\hline 2 & Demokratis & $\begin{array}{l}\text { Pada pola asuh ini orang tua yang tetap membuat tuntutan atau } \\
\text { permintaan untuk anak, orangtua menjelaskan kepada anak tentang } \\
\text { alasan kepada anak dalam mematuhi sebuah aturan dan memastikan } \\
\text { anak mengikuti aturan tersebut. Dengan tetap memberikan kebebasan } \\
\text { pada anak untuk mengemukakan pendapat dan melakukan apa yang } \\
\text { diinginkan oleh anak dengan tetap mematuhi batasan serta aturan yang } \\
\text { telah ditetapkan oleh orang tua, yang juga sisertai dengan bimbingan dan } \\
\text { pengertian orang tua. Jika anak gagal dalam memenuhi harapannya } \\
\text { maka orang tua akan memilih memaafkan daripada menghukum } \\
\text { anaknya. Orang tua dalam Pengasuhan ini (authoritative) mendorong } \\
\text { untuk saling membantu dan bertindak sacara obyektif. Orangtua } \\
\text { cenderung tegas tetapi hangat dan penuh perhatian sehingga anak } \\
\text { tampak ramah, kreatif dan percaya diri, mandiri, dan bahagia serta } \\
\text { memiliki tanggung jawab sosial. Orangtua bersikap bebas atau longgar } \\
\text { namun masih dalam batas-batas normatif(Adpriyadi \& Sudarto, } \\
\text { 2020);(Casmini,2007:8) }\end{array}$ \\
\hline 3 & Permisif & $\begin{array}{l}\text { Pola asuh orang tua yang memberi banyak kebebasan namun kurang } \\
\text { akan pengawasan terhadap perilaku anak. Anak mendapat kebebasan } \\
\text { mengatur dirinya sendiri. Tidak ada tuntutan bagi anak untuk belajar } \\
\text { bertanggung jawab. Sebagai akibat dari pola asuh ini terhadap } \\
\text { kepribadian anak kemungkinannya adalah agresif, menentang atau tidak } \\
\text { dapat bekerjasama dengan orang lain, emosi kurang stabil, selalu } \\
\text { mengalami kegagalan karena tidak ada bimbingan Khasanah \& Fauziah, } \\
\text { 2020); (Yusuf: 2006) }\end{array}$ \\
\hline 4 & $\begin{array}{l}\text { Pola asuh } \\
\text { penelantaran } \\
\text { atau tidak } \\
\text { terlibat }\end{array}$ & $\begin{array}{l}\text { pola asuh orang tua yang cenderung pada penelantaran anak dan bahkan } \\
\text { sama sekali tidak terlibat apapun terkait diri sang anak baik secara fisik } \\
\text { maupun psikis. Pola asuh ini biasanya terjadi terjadi pada keluarga yang } \\
\text { bermasalah. Orang tua pada pola asuh ini lebih menolak anak dan tidak } \\
\text { punya waktu dan energi untuk mengasuh dan membesarkan anak } \\
\text { mereka. Orang tua memenuhi kebutuan dasar anak tapi mereka tidak } \\
\text { memperdulikan kehidupan anak mereka(maccoby dan martin dalam } \\
\text { shaffer ,2008:376); (Handayani et al., 2020). }\end{array}$ \\
\hline
\end{tabular}

Faktor yang mempengaruhi gaya pengasuhan kakek dan nenek

Dalam pengasuhan anak usia dini (cucu) Gaya kakek-nenek dipengaruhi oleh sejumlah faktor individu, lingkungan, dan sosial ekonomi, terutama otoritas dan mengontrol satu latihan atas cucu. Berikut dijelaskan bahwa faktor individu ini terkait dengan posisi kekrabatan yang mana cucu ari pihak ibu cenderung memiliki kontak serta kehangatan yang lebih besar; jenis kelamin hingga usia cucu dan usia kakek dan nenek mempengaruhi interaksi yang muncul.

Kualitas hubungan antara kakek-nenek dan anak-anaknya yang sudah dewasa memiliki pengaruh utama pada peran kakek-nenek; juga,Penelitian secara konsisten 
menunjukkan bahwa kualitas hubungan antara kakek dan nenek mempengaruhi kuantitas kontak antara kakek-nenek dan cucu-cucu itu. Selanjutnya, ras / etnis memengaruhi gaya kakek-nenek. Gaya yang lebih sering ditemukan dalam keluarga minoritas termasuk gaya keluarga sejarawan atau leluhur yang masih hidup, yang mengajarkan tradisi, pengalaman, budaya, dan sejarah etnis kepada cucu. Secara keseluruhan, kakek memang bisa memuaskan bagi mereka yang memberikan makna positif pada peran tersebut, yang gayanya menciptakan kesempatan untuk berinteraksi dengan cucu, dan yang hubungannya dengan anak dewasa mereka positif. (Hakoyama et al., 2016)

\section{Perilaku prososial anak usia dini}

Perilaku prososial merupakan salah satu dasar perkembangan yang harus dimiliki anak, karena sangat diperlukan untuk persiapan diri menjadi anggota kelompok dalam akhir masa kanak-kanak nantinya serta untuk beradaptasi dengan lingkungan yang lebih luas. Perilaku prososial adalah suatu perilaku moral positif yang bertujuan memberi manfaat pada orang lain (Santrock, 2013). sejalan dengan hal tersebut pendapat lain menjelaskan bahwa, Perilaku prososial adalah perilaku yang mencerminkan kepedulian dan perhatian dari seorang anak ke anak lainnya, misalnya dengan membantu, menghibur, atau hanya tersenyum pada anak lain (Beaty, 2013)

Perilaku prososial merupakan tindakan sukarela dengan niat untuk membantu orang lain (Papalia et al., 2014). Perilaku prososial adalah tindakan sukarela dengan maksud membantu dan memberikan manfaat kepada orang lain, yaitu berbagi (memberikan barang atau cerita), menolong (melakukan sesuatu untuk memudahkan pihak kedua), menunjukkan kasih sayang secara fisik agar pihak kedua merasa lebih nyaman dan tenang, memberikan dukungan (memberikan semangat atau kesempatan kepada orang lain), serta kerjasama(Eisenberg \& Mussen, 1989). Dalam pendapat lain dijelaskan bahwa, Perilaku prososial adalah semua tindakan apapun yang dilakukan untuk keuntungan orang lain atau secara umum dapat disimpulkan suatu tindakan yang berupa menolong orang lain yang mendapatkan pertolongan tanpa harus menerima imbalan atau balasan yang dirasakan langsung oleh orang yang memberikan pertolongan, walaupun terkadang perilaku tersebut mengadung resiko bagi orang yang memberikan pertolongan (Pratama et al., 2016).

Sesuai dengan berbagai pendapat yang ada, dapat disimpulkan bahwa perilaku prososial adalah semua perilaku yang mencerminkan perhatian dan kepedulian anak kepada orang lain yang dapat berupa tindakan sukarela dengan maksud membantu pekerjaan anak lain.

\section{Bentuk-bentuk Perilaku Prososial}

Salah satu perilaku yang harus dimiliki anak prasekolah yakni perilaku prososial(Permendikbud, 2014). Sejalan dengan pendapat tersebut (Eisenberg \& Mussen, 1989) membagi perilaku prososial menjadi dua kategori, yaitu perilaku prososial spontan dan perilaku prososial berdasarkan permintaan. Kategori tersebut didasarkan pada motivasi yang mendasari munculnya perilaku prososial. Perilaku prososial spontan berhubungan dengan orientasi anak terhadap orang lain, penjelasan empati untuk keputusan moral, serta tingginya tingkat kemampuan untuk bersosialisasi dengan teman sebayanya. Misalnya ketika ada teman sebaya yang menangis, maka anak-anak berusaha menenangkan teman tersebut. Perilaku prososial yang kedua adalah perilaku prososial yang muncul berdasarkan permintaan teman sebaya. Misalnya, ada anak yang kehilangan pensil dan menanyakan kepada temannya, kemudian temannya mencarikan pensil tersebut.

Dalam pendapat lain bentuk -bentuk perilaku prososial memiliki beberapa macam, dalam uraian pada tabel 3 .

Tabel 3. Bentuk-bentuk perilaku sosial 


\begin{tabular}{|c|c|}
\hline Perilaku & Penjelasan \\
\hline Empati & $\begin{array}{l}\text { Merupakan kemampuan merasakan seperti yang dirasakan orang lain. Empati } \\
\text { merupakan selangkah lebih maju dari simpati belaka dimana seseorang bisa } \\
\text { merespons secara emosional terhadap orang lain tetapi dari sudut pandangnya } \\
\text { sendiri. Empati adalah dasar dari semua perilaku prososial. Tanpa kemampuan ini, } \\
\text { seorang anak tidak akan mampu bersikap secara alami dalam satu prilaku } \\
\text { menolong, berbagi, dan penuh kasih sayang. }\end{array}$ \\
\hline Perhatian & $\begin{array}{l}\text { Merupakan suatu perilaku yang menunjukkan kesediaan seorang anak melakukan } \\
\text { sesuatu baik diminta ataupun sukarela saat melihat temannya dalam kesusahan. } \\
\text { Kepedulian merupakan bentuk lanjut dari perilaku membantu yang orang lain yang } \\
\text { membutuhkan namun melibatkan kasih sayang atau dukungan psikologis dengan } \\
\text { tindakan fisik memberikan bantuan. }\end{array}$ \\
\hline $\begin{array}{l}\text { Berbagi } \\
\text { (Sharing) }\end{array}$ & $\begin{array}{l}\text { Yaitu kesedian memberikan bantuan atau pertolongan kepada orang lain yang } \\
\text { sedang mengalami kesulitan, baik berupa moril maupun materiil. Menolong } \\
\text { meliputi membantu orang lain atau menawarkan sesuatu yang menunjang } \\
\text { berlangsungnya kegiatan orang lain. }\end{array}$ \\
\hline $\begin{array}{l}\text { Kerjasama } \\
\text { (Cooperating) }\end{array}$ & $\begin{array}{l}\text { Yaitu kesediaan untuk bekerja sama denagn orang lain demi tercapainya suatu } \\
\text { tujuan. Cooperating biasanya saling menguntungkan, saling memberi, saling } \\
\text { menolong dan menenangkan. }\end{array}$ \\
\hline $\begin{array}{l}\text { Bertindak } \\
\text { jujur } \\
\text { (Honesty) }\end{array}$ & $\begin{array}{l}\text { Yaitu kesediaan untuk melaukukan sesuatu seperti apa adanya, tidak berbuat } \\
\text { curang terhadap orang lain }\end{array}$ \\
\hline $\begin{array}{l}\text { Dermawan } \\
\text { (Donating) }\end{array}$ & $\begin{array}{l}\text { Yaitu kesedian untuk memberikan secara sukarela sebagian barang miliknya } \\
\text { kepada orang yang membutuhkannya. (Eisenberg \& Mussen dalam Dayakisni dan } \\
\text { Hudaniah, 2009: 175; Janice J. Beaty, 2013) }\end{array}$ \\
\hline
\end{tabular}

\section{Faktor yang mempengaruhi perilaku prososial pada anak usia dini}

Faktor Yang Mempengaruhi Seseorang Melakukan Perilaku Prososial Menurut Sarwono (2009:134-138) antara lain: (1) Suasana hati (mood), emosi positif dan negative mempengaruhi kemunculan tingkah laku menolong. (2) Sifat, berbagai karateristik seseorang mempengaruhi kecenderungannya untuk menolong, salah satunya adalah artuistik. Salah satu aspek-aspek salam kepribadian artuistik yaitu empati. (3) Jenis kelamin, peranan gender terhadap kecenderungan untuk menolong sangat dipengaruhi oleh situasi dan bentuk pertolongan yang dibutuhkan. (4) Tempat tinggal, lingkungan dimana seseorang tinggal mempengaruhi kecenderungan dalam tingkah laku menolong, semisal saja orang yang tinggal di desa cenderung lebih suka menolong dari pada orang yang tinggal di kota. (5) Pola asuh, pola asuh orang tua yang demokratis mendukung terbentuknya tingkah laku menolong pada seseorang.

Sejalan dengan pendapat tersebut, Faktor-faktor yang mempengaruhi perilaku prososial meliputi pola asuh orangtua dan peran keluarga sebagai model dan sumber patokan dari perilaku prososial. Selain itu, interaksi dengan teman sebaya juga menyediakan kesempatan bagi anak untuk berperilaku prososial maupun menerima perilaku prososial dan merupakan sumber penting feedback (Killen \& Smetana, 2006, h. 562). Budaya dan sistem pendidikan sekolah juga berpengaruh terhadap perkembangan perilaku prososial anak usia dini.

Sesuai dengan pendaat diatas, faktor yang mempengaruhi perkembangan perilaku prososial adalah dari lingkungan keluarga berupa pola asuh orang tua, suasana hati, sifat, lingkungan sekitar tempat tinggal, dan juga teman sebaya.

Pada upaya pengasuhan kakek nenek terhadap cucu (anak usia dini) tentu tidak selalu berhasil dalam pelaksanaannya. Saat ini pengasuhan oleh kakek nenek cenderung kepada pengasuhan yang memanjakan atau membebaskan kemauan cucu mereka yang merupakan pengasuhan permissive. Hal Ini sejalan dengan yang dijelaskan oleh baumrind dalam gafor \& Kurukkan, (2014) mencerminkan perlakukan kehangatan dan kasih sayang, penegakan 
wewenang dan aturan yang rendah, unsur penerimaan yang tinggi, mengambil peran sebagai teman dari pada induk, membiarkan anak membuat keputusan sendiri dan sangat minimal sekali dalam menggunakan hukuman. Hal ini sangat tidak ideal di sebabkan pada pengasuhan oleh kakek nenek yang mengasuh cucu serta sebagai perwalian dapat menimbulkan masalah pada perilaku anak. Hal ini sesuai dengan penjelasan dalam the power of positive parenting bahwa anak yang dalam pengasuhan dan perawatan oleh kakek nenek mengalami peningkatan pada tingkat hoeraktif dan kesulitan dalam bergaul. Pada tingkat usia yang lebih tinggi terkait dengan keterlibatan kakek nenek yang lebih besar cenderung meningkatkan secara signifikan pada perilaku prososial(Sanders \& Mazzucchelli, 2018).

\section{SIMPULAN}

Pengasuhan kakek dan nenek mempunyai pengaruh yang besar pada anak usia dini. Pada proses pengasuhan kakek nenek pada umumnya menggunakan pola pengasuhan permisif yang cenderung memberi kebebasan dan minim teguran, yang dapat berdampak buruk terkait dengan kondisi psikologis pada anak usia dini(cucu) menjadi menarik diri dari lingkungan dan mengalami kesulitan dalam bergaul dengan teman sebayanya. Kondisi ini tentu dapat menyebabkan perilaku prososial anak belum berkembang dengan optimal.

\section{UCAPAN TERIMA KASIH}

Penulis mengucapkan terimakasih kepada Prof. Dr. Dimyati, M.Si atas bimbingan yang telah diberikan dalam proses penulisan artikel ini. Semoga Allah SWT memberi berkah atas ilmu yang telah bapak berikan, aamiln ya rabbal'alamiin.

\section{DAFTAR PUSTAKA}

Adpriyadi, A., \& Sudarto, S. (2020). Pola Asuh Demokratis Orang Tua Dalam Pengembangan Potensi Diri Dan Karakter Anak Usia Dini. VOX EDUKASI: Jurnal Ilmiah Ilmu Pendidikan, 11(1), 26-38. https:// doi.org/10.31932/ve.v11i1.572

Beaty, J. J. (2013). Observasi Perkembangan Anak Usia Dini (Edisi Ketujuh) (A.K. Anwar (ed.); Edisi Ketu). KENCANA.

Drew, L. M., Richard, M. H., \& Smith, P. K. (1998). Grandparenting and its relationship to parenting. In Clinical Child Psychology and Psychiatry (Vol. 3, Issue 3, pp. 465-480). SAGE Publication. https:// doi.org/10.1177/1359104598033009

Eisenberg, N., \& Mussen, P. H. (1989). The Roots Of Prosocial Behavior In Children. Cambridge University Press. https:// doi.org/10.1017/CBO9780511571121

Fono, Y. M., Fridani, L., \& Meilani, S. M. (2019). Kemandirian dan Kedisplinan Anak yang Diasuh oleh Orangtua Pengganti. Jurnal Obsesi : Jurnal Pendidikan Anak Usia Dini, 3(2), 537. https:// doi.org/10.31004/obsesi.v3i2.245

Hakoyama, M., MaloneBeach, E. E., Hayslip, B., \& Page, K. S. (2016). Grandparenthood. In The Curated Reference Collection in Neuroscience and Biobehavioral Psychology (Issue October 2016, pp. 261-267). https://doi.org/10.1016/B978-0-12-809324-5.06440-3

Handayani, R., Purbasari, I., \& Setiawan, D. (2020). Tipe-Tipe Pola Asuh Dalam Pendidikan Keluarga. Refleksi Edukatika: Jurnal Ilmiah Kependidikan, 11(1), 16-23. https://doi.org/10.24176/re.v11i1.4223

Hasanah, N., \& Sugito, S. (2020). Analisis Pola Asuh Orang Tua terhadap Keterlambatan Bicara pada Anak Usia Dini. Jurnal Obsesi : Jurnal Pendidikan Anak Usia Dini, 4(2), 913. https://doi.org/10.31004/obsesi.v4i2.456

Ingersoll-Dayton, B., Tangchonlatip, K., \& Punpuing, S. (2020). A Confluence of Worries: Grandparents in Skipped-Generation Households in Thailand. Journal of Family Issues, 41(2), 135-157. https:// doi.org/10.1177/0192513X19868836 
Kartika, A. D. A., Malik, L. R., \& Saugi, W. (2020). Pola Asuh Orang Tua Dalam Pendidikan Karakter Anak Usia Dini. Southeast Asian Journal of Islamic Education, 3(1), 2020. https:// doi.org/10.30631/smartkids.v1i2.55

Kemenpppa. (2009). Undang-Undang Republik Indonesia Nomor 52 Tahun 2009 Tentang Perkembangan Kependudukan Dan Pembangunan Keluarga. In Republik Indonesia.

Khasanah, B. L., \& Fauziah, P. (2020). Pola Asuh Ayah dalam Perilaku Prososial Anak Usia Dini. Jurnal Obsesi: Jurnal Pendidikan Anak Usia Dini, 5(1), 909-922. https://doi.org/10.31004/obsesi.v5i1.627

Knafo, A., \& Plomin, R. (2006). Prosocial behavior from early to middle childhood: Genetic and environmental influences on stability and change. In Developmental Psychology (Vol. 42, Issue 5, pp. 771-786). https://doi.org/10.1037/0012-1649.42.5.771

Minuchin, S. (1974). Families \& Family Therapy. Harvard University Press, 53(9), 281.

Mueller, M. M., Wilhelm, B., \& Elder, G. H. (2002). Variations in grandparenting. Research on Aging, 24(3), 360-388. https://doi.org/10.1177/0164027502243004

Nasution, M. K. M. (2017). Penelaahan literatur.

Papalia, D. E., Martorell, G., \& Feldman, R. D. (2014). A Child ' S World in the City : Infancy Through Adolescence.

Permendikbud. (2014). Standar Nasional Penilian PAUD Nomor 137 tahun 2014. Menteri Kesehatan Republik Indonesia Peraturan Menteri Kesehatan Republik Indonesia, Nomor 65(879), 2004-2006.

Pratama, D., Hidayah, R., \& Hargiyansari, T. (2016). Peran pendidik dalam menumbuhkan perilaku prososial anak dengan media permainan tradisional. Seminar Nasional Hasil Penelitian Kepada Masyarakat UNIPMA, 20-23.

Sanders, M. R. [Ed], \& Mazzucchelli, T. G. [Ed]. (2018). The power of positive parenting: Transforming the lives of children, parents, and communities using the Triple $\mathrm{P}$ system. In M. R. Sanders \& Trevor G. Mazzucchelli (Eds.), The power of positive parenting: Transforming the lives of children, parents, and communities using the Triple $\mathrm{P}$

system. http://ovidsp.ovid.com/ovidweb.cgi?T=JS\&PAGE=reference\&D=psyc15\&NEWS=N \&AN=2018-09030-000

Santrock, J. W. (2013). Child Development : Fourteenth Edition. In S. Colwell (Ed.), McGrawHill Education (Vol. 53, Issue 9). McGraw- Hill Education.

Sofiani, I. K., Mufika, T., \& Mufaro'ah, M. (2020). Bias Gender dalam Pola Asuh Orangtua pada Anak Usia Dini. Jurnal Obsesi: Jurnal Pendidikan Anak Usia Dini, 4(2), 766. https://doi.org/10.31004/obsesi.v4i2.300

Wekke, I. S. (2020). Metode Penelitian Ekonomi Syariah (Issue September). Penerbit Gawe Buku (group Penerbit CV. Adi Karya Mandiri).

Zakaria, \& Alif, M. R. (2020). Pengalihan peran sementara pengasuhan anak dari orang tua ke nenek dan kakek. Jurnal Sosiologi Dialektika, 14(2), 120. https://doi.org/10.20473/jsd.v14i2.2019.120-125 